\title{
THE DEVELOPMENT OF FINANCIAL STATEMENT ANALYSIS LEARNING MEDIA TO ENHANCE STUDENT ANALYSIS ABILITIES
}

\author{
Dedy Husrizal Syah ${ }^{1}$ \\ Accounting \\ State University of Medan \\ dedy@unimed.in* \\ Taufik Hidayat ${ }^{3}$ \\ Accounting \\ State University of Medan \\ hidayatunimed@gmail.com
}

\author{
La Ane ${ }^{2}$ \\ Accounting \\ State University of Medan \\ Laane_gu@ymail.com \\ Haikal Rahman ${ }^{4}$ \\ Civil Engineering Education \\ State University of Medan \\ haikalrahman@unimed.in
}

\begin{abstract}
This study aims to develop financial report analysis learning media based on mobile learning; by testing the feasibility level of the developed learning media based on validation/assessment that carried out by the expert teams and students. The Validation of Learning Media that carried out by the Media Expert team (Lecturer) and as well as testing the student analytical abilities were tested towards 40 students accounting program of State University of Medan 2018. The data analysis method used is a descriptive analysis of the percentage. In general, the media validation results fall into the category very viable whereas the result of field trial assessment also categorized as very viable.
\end{abstract}

Keywords:

Learning media; mobile learning; analysis ability

\section{ABSTRAK}

Penelitian ini bertujuan untuk mengembangkan media pembelajaran analisis laporan keuangan berbasis mobile learning; dengan menguji tingkat kelayakan media pembelajaran yang dikembangkan berdasarkan validasi/penilaian dari tim ahli dan mahasiswa serta pengujian kemampuan analisis mahasiswa. Validasi media dilakukan oleh Tim Dosen Ahli Media dan diujicobakan kepada 40 mahasiswa program studi Akuntansi Universitas Negeri Medan stambuk 2018. Teknik analisa data yang digunakan adalah teknik deskriptif presentase. Secara garis besar, hasil validasi aspek media tergolong kategori sangat layak dan hasil penilaian ujicoba lapangan juga tergolong kategori sangat layak.

Kata Kunci: $\quad$ Media pembelajaran; mobile learning; kemampuan analisis

JEL Cassification: A220; M200

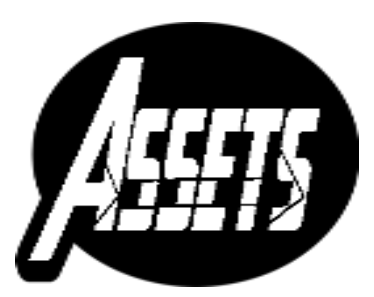

ASSETS

Jurnal Akuntansi dan Pendidikan

Vol. 9 No. 1

Hlmn. 30-40

Madiun, April 2020

p-ISSN: 2302-6251

e-ISSN: 2477-4995

Artikel masuk: 1 November 2019 Tanggal diterima: 22 April 2020

${ }^{*}$ corresponding author 


\section{INTRODUCTION}

The development of the digital world today has an impact on various aspects of life, including the education world that can bridge the present with the future. The application of Information and Communication Technology to the Educational Workforce Education Institution has become an obligation, because the implementation of ICT can be one of the indicators for these educational institutions, one of them is State University of Medan. The purpose of integrating ICT in the teaching competency approach in the world of learning, namely 1) increasing the use of technology by students, the community, and the workforce by incorporating technology skills into the school/institution curriculum, 2) increasing the ability of students/students of collage, the community, and workforce in using knowledge to add value to society and economic productivity by applying complex problems in the real world, 3) increasing the ability of students/students of collage, society, and labor to innovate to produce a new knowledge and to get the benefit from new knowledge (UNESCO, 2011). Online learning is one form of technological progress made by teaching staff in learning. The development of educational progress has been marked by a learning process that is not centered on the teaching staff.

In recent years there is known the term of mobile learning, where mobile media/smartphones and tablets are used to access online learning. Learning services that can be done anywhere and anytime include using mobile-based learning media (Aripin, 2018). The use of mobile phones makes it easy for everyone to access the internet, even though it is not only sourced from technology, the pattern of human life has become modern and easy. This can be seen from some previous research on the use of the latest information and communication technology (Febriani, 2017).

The development of learning media for analytical courses on financial reports based on mobile learning can be a breakthrough to increase the potential for smartphone use in the 21st century. In the era of industrial revolution 4.0, the world of education is faced with digitalization, optimization, and the use of information technology which is one of the references starting in 2018 and has become one of the principles of the industrial revolution 4.0. One of the advantages of using mobile-based learning media is in terms of form and visualization. Another advantage gained in the development of mobile-based learning is in terms of time and place that is very flexible (Calimag, 2014). Although both are them require an internet connection, in terms of price, handphones are still a cheaper category compared to laptops and desktop PCs. There are 4 (four) rational reasons why learning media is very important to be used in the learning process, namely (1) to improve the quality of learning, (2) as demands for a new paradigm, (3) for market needs, (4) as a vision of global education (Ashhar, 2011).

Some Previous studies that related to this media have been carried out both nationally and internationally, including showing the use of mobile learning media can improve students' understanding of electronics subjects (El-Mouelhy et al., 2013; Hakim, 2015) shows the use of tablets in learning can also improve the understanding of the material subject to students. On the other research also shows clearly that the development of educational media based on Android-assisted educational games can increase student enthusiasm in learning and not get bored (Yana et al., 2019).

One of the subjects that are still considered difficult by students is the Financial Statement Analysis course. This material is considered difficult because it requires students to have the ability to analyze various financial reporting activities. Referring to the results of previous research, the author tries to re-implement learning media

This work is licensed under a Creative Commons Attribution-ShareAlike 4.0 International License. 
based on mobile learning in one of the most popular subjects in the field of accounting, namely financial statement analysis.

One of the software/applications that can be used in designing mobile-based learning is AppyPie. AppyPie is relatively easy to use because it doesn't require any programming skills. Appy Pie is also a cloud-based application for developing an application for Windows, Android and iOS, and publishing it to Google Play or iTunes using the drag and drop system. Appypie can be accessed by opening the site www.appypie.com (Setiani, 2018).

\section{METHOD}

This research will produce an application product, therefore this type of research includes research and development (Sugiyono, 2010). This media research and development step was adopted from the Borg \& Gall Model (1983, pp. 589-594) which consisted of 10 steps, namely: (1) research and information gathering; (2) planning; (3) development of preliminary product forms; (4) preliminary trials; (5) revisions to major products; (6) field/class trials involving students; (7) product revisions and modifications; (8) retake in class; (9) final revisions and modifications; and (10) dissemination and implementation. However, in this study the steps were modified into 5 (five) stages: (1) the analysis phase; which consists of preparing to analyze the character of students, and analysis of the material, (2) the design phase; designing a learning media application flowchart or storyboard, (3) the development phase; this stage is a revision of the design stage where the instructional media that have been designed are validated for their feasibility by a team of media experts, (4) the implementation phase; the stage of testing the media product to users, in this case, students, (5) the evaluation stage; the final stage of assessment of learning media products that have been made.

\section{Table 1. The Instrument of the Trial Material Assessment}

\begin{tabular}{llc}
\hline \multicolumn{1}{c}{ Aspect } & \multicolumn{1}{c}{ Indicator } & Number of Question \\
\hline The truth of & The clarity of learning objective & 1 \\
& & 2 \\
\cline { 2 - 3 } & The truth of material subject seen from & 3 \\
& scientific aspects & 4 \\
\cline { 2 - 3 } & The using of language & 5 \\
Material & The suitable of material & 6 \\
Arrangement & & 7 \\
& The depth of material & 8 \\
\cline { 2 - 3 } & & 9 \\
\cline { 2 - 3 } & Contextually & 10 \\
\cline { 2 - 3 } & & 11 \\
& The completeness of supporting materials & 12 \\
\hline Potential & The easy material to understand & 13 \\
& & 14 \\
\cline { 2 - 3 } & The flows of clear logic & 15 \\
& & 16 \\
\cline { 2 - 3 } & Interactivity & 18 \\
& & 19 \\
& & 20
\end{tabular}


This research was conducted at the State University of Medan in particular the Accounting Study Program, The study was conducted in July of October 2019. The research subjects consisted of the subject of the team of media validation experts and students as subjects of field trials. The subject of media validation includes two media experts. Product trials are field trials. The field trial subjects are students taking Financial Statement Analysis courses in the current semester with details of 40 people. The design of this media application product is carried out using one of the online builders available on the internet based on cloud called by AppyPie.

The data collected in this study used a questionnaire/instrument of media validation and a trial instrument. The media validation instrument contains a media validation sheet aimed at the learning media expert team while the trial instrument is a quality assessment material sheet aimed at students (used in field trials). This instrument was adopted from Anggraeni \& Kustijono's Research Instrument (2013). The indicators of the trial material assessment instruments and the assessment of media experts are presented in Table 1 and 2.

Table 2. The Instruments of Media Expert Assessments

\begin{tabular}{llc}
\hline \multicolumn{1}{c}{ Aspect } & \multicolumn{1}{c}{ Indicator } & Number of Question \\
\hline Interface & Consistency & 1 \\
& Easy to understand & 2 \\
& Clear instructions & 3 \\
& The presentation of navigation & 4 \\
& Order of appearance & 5 \\
& Clear colors, font, and text & 6 \\
& The quality of the interface & 7 \\
\hline Multimedia & The suitability of picture & 8 \\
& The suitability of element combination & 9 \\
& The presentation of multimedia & 10 \\
& The suitability of contents & 11 \\
& The displays of elements in one screen & 12 \\
\hline
\end{tabular}

Instrument validation in this research was measured using a Likert scale. The results of the analysis of the instrument will get a score of each instrument then the average instrument is calculated using the formula:

$$
\mathrm{x}=\Sigma \mathrm{x} / \mathrm{n}
$$

$$
\begin{array}{cl}
\text { Notes : } \mathrm{x} & =\text { average score } \\
\Sigma \mathrm{x} & =\text { item total score } \\
\mathrm{n} & =\text { number of items }
\end{array}
$$

After getting an average score of each instrument, then calculate the percentage of eligibility with the formula:

Percentage of eligibility $(\%)=($ observation score) $/$ (ideal score) $\times 100 \%$

The percentage results are then matched with the Likert scale predicate (Likert, 2017). The Likert scale assessment provisions in this study are explained in Table 3. 
Table 3. Likert Scale Assessment

\begin{tabular}{ccc}
\hline No & Percentage & Interpretation \\
\hline 1 & $0 \%-20 \%$ & Very Unviable \\
2 & $21 \%-40 \%$ & Unviable \\
3 & $42 \%-60 \%$ & Viable Enough \\
4 & $61 \%-80 \%$ & Viable \\
5 & $81 \%-100 \%$ & Very Viable \\
\hline
\end{tabular}

Source: adapted from Likert, 2017

Whereas at the stage of student analytical skills, test subjects derived from pretest and posttest scores can use a normalized gain score. The normalization of the gain is measured by the n-Gain formula pioneered by Hake as follows (Hake, 1999):

Normalized gain $(\mathrm{G})=$ (post-score pretest score) / (ideal score-pretest score) ..(3)

The conclusion reached was based on the n-Gain category and is explained in Table 4.

Tabel 4. Modified Normalized Gain Interpretation Criteria

\begin{tabular}{cc}
\hline Score of Normalized Gain & Interpretation \\
\hline$-1,00-1,00<\mathrm{g}<0,00$ & Decrease \\
$\mathrm{g}=0,00$ & No Increase \\
$0,00<\mathrm{g}<0,30$ & Low \\
$0,30<\mathrm{g}<0,70$ & Medium \\
$0,70<\mathrm{g}<1,00$ & High \\
\hline
\end{tabular}

Source : adapted from Hake, 1999

\section{RESULT AND DISCUSSION}

Following the results of the model development stages that have been carried out, consisting of (1) the results obtained the student character analysis stage stated that most of the students wanted the lecture process to be different from the usual, especially in-class learning, because the Financial Statement Analysis course was very crucial but in several universities, these courses were dominantly taught at lecture hours are very boring, while the results of identification at the material analysis stage, the author tries to divide some of the subjects that become the main material in learning Financial Analysis courses, including a) Trend Analysis, b) Ratio Analysis, c) Analysis of Sources and Use of Working Capital, d) Analysis of Sources and Uses of Cash, e) and Analysis of Changes in Revenue.

Table 5. The Result of Student Character Analysis

\begin{tabular}{cc}
\hline Character & Total (\%) \\
\hline Learning interest & 84 \\
Renewed interest & 92 \\
\hline
\end{tabular}

(2) The stage of product design is done by making product designs in the form of flowcharts and storyboards. Flowchart illustrates the flow of learning media research on mobile devices triumph in Figure 1. The storyboard evaluates completely the arrangement of images, writing, effects, animation, and other components on the media learning screen display. The design of learning media products Financial Analysis is carried out using the AppyPie Builder delivered with Corel Photoimpact. (3) The development phase is carried out by validating the media expert instruments 
by 2 (two) Lecturers Supporting the Financial Statement Analysis Course. And at this stage also modify media products by table 6 about the recommendation of media expert.

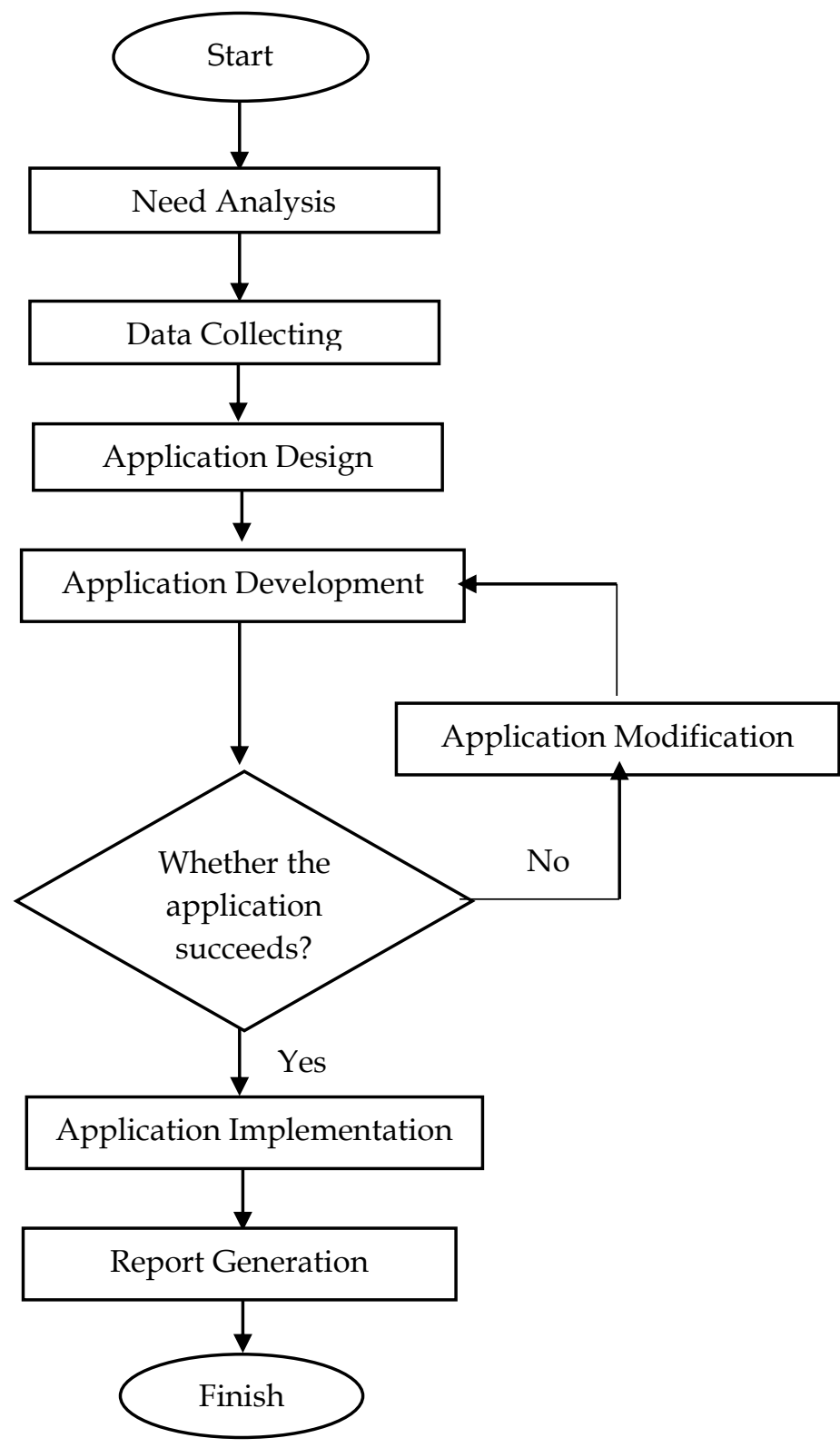

Figure 1. Research Flowchart

Table 6. The Suggestion and Recommendation of Media Expert

\begin{tabular}{ccc}
\hline No & Validator & The comments of Suggestions and Improvements \\
\hline 1 & Media Expert 1 & $\begin{array}{r}\text { The image will be interesting if it gave a soft background } \\
\text { color and the color of the object }\end{array}$ \\
2 & Media Expert 2 & Animated images will support active student responses \\
\hline
\end{tabular}

(4) Stage of field trials for students totaling \pm 40 people. (5) Final Evaluation Phase is carried out by evaluating the trial of products in the field using instruments/questionnaires about the feasibility of the material. The output of the 
media product is in the form of an APK file that can be opened on the appropriate mobile device and then automatically installs the learning media on the mobile device.

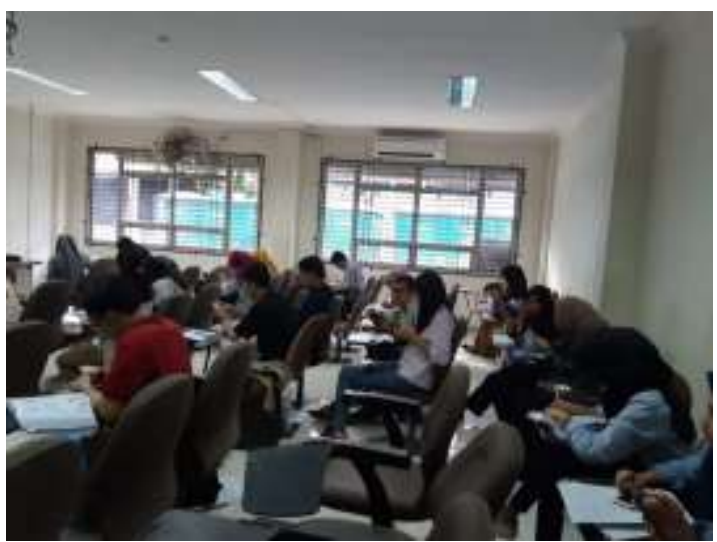

Figure 2. Enthusiastic of Students in Using mobile learning

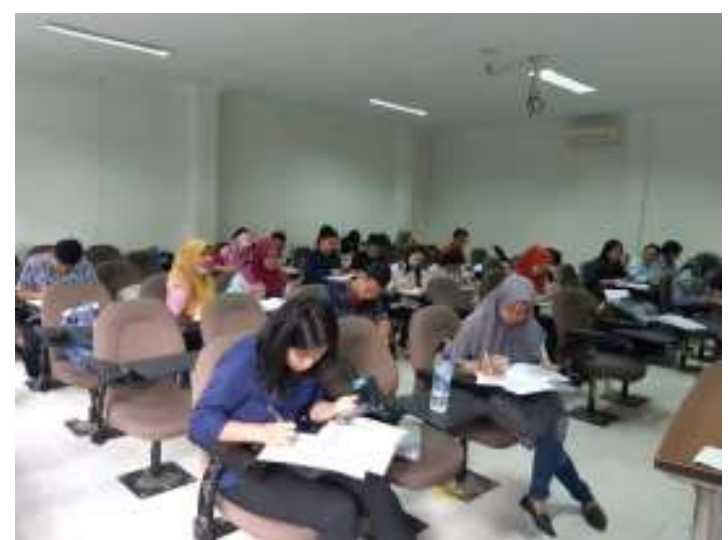

Figure 3. The Trial Process in Class

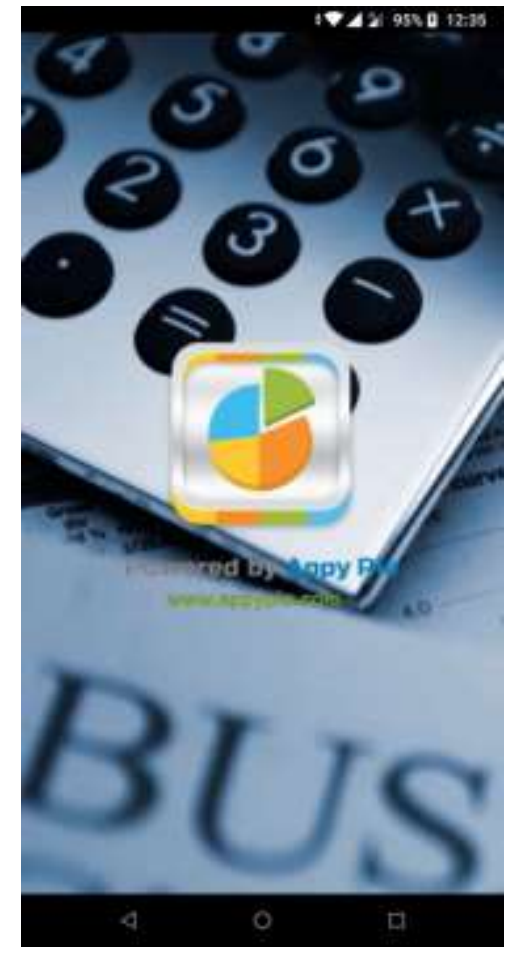

Figure 4. Main Menu Display

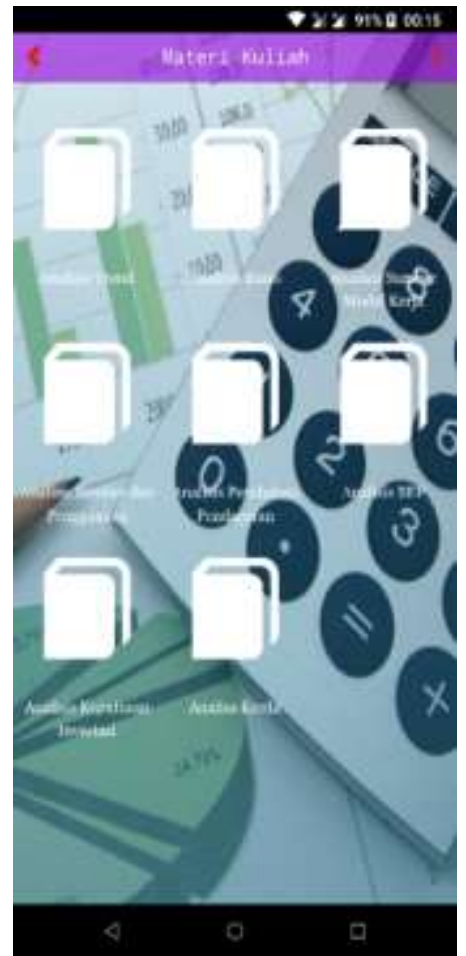

Figure 5. Document

Material Menu Display

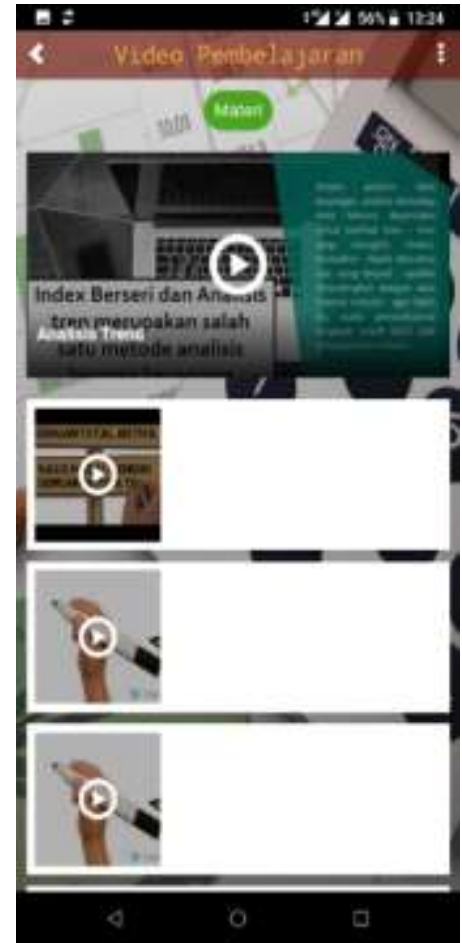

Figure 6. Video

Material Menu

Display

Product validation was carried out by two media experts namely the Lecturer Support Team for Financial Statement Analysis Courses, the product validation was carried out using a media assessment instrument that had been validated by a research instrument validator in content and construct. The media expert team conducted an assessment based on 2 (two) aspects, namely the interface aspect which gave $88.57 \%$ results, and the multimedia aspect results $90 \%$, so that it can be categorized as very viable. The following figure 7 diagram results about the assessment of media experts. 


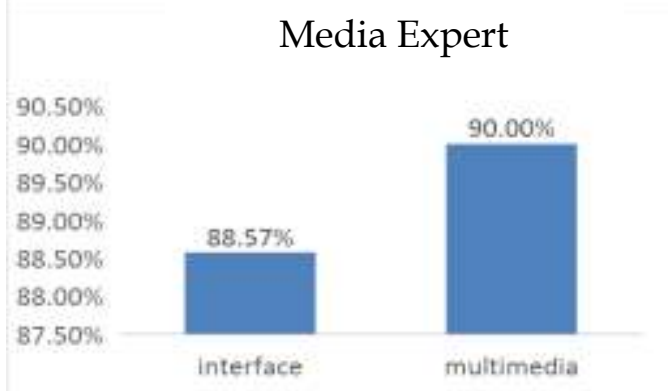

Figure 7. Diagram of the Media Expert Assessment

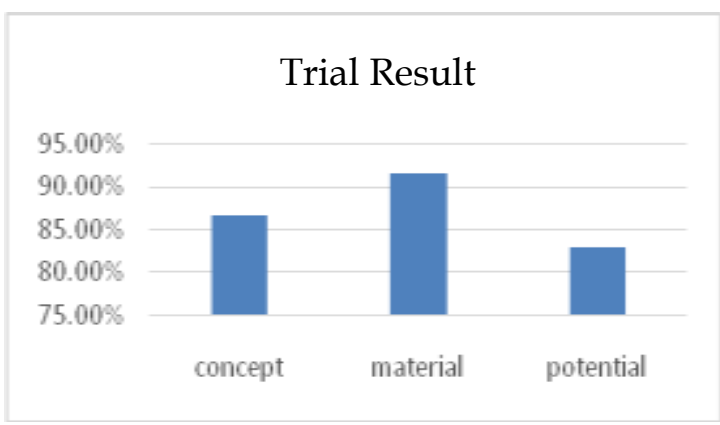

Figure 8. Diagram of Field Trial Assessment

The results of the assessment of field trials to students of the learning media products developed were assessed at the validation stage consisting of the true aspect of the concept is $86.67 \%$, the content preparation is $91.43 \%$ and the potential aspect is $82.86 \%$. The results of this trial evaluation were stated at $86.89 \%$ so that they could also be categorized as very viable.
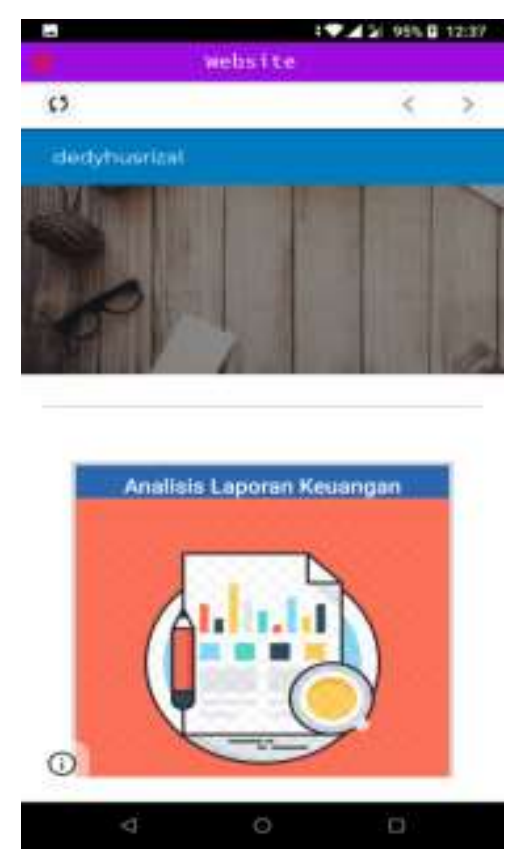

Figure 9. Site Material Menu Display

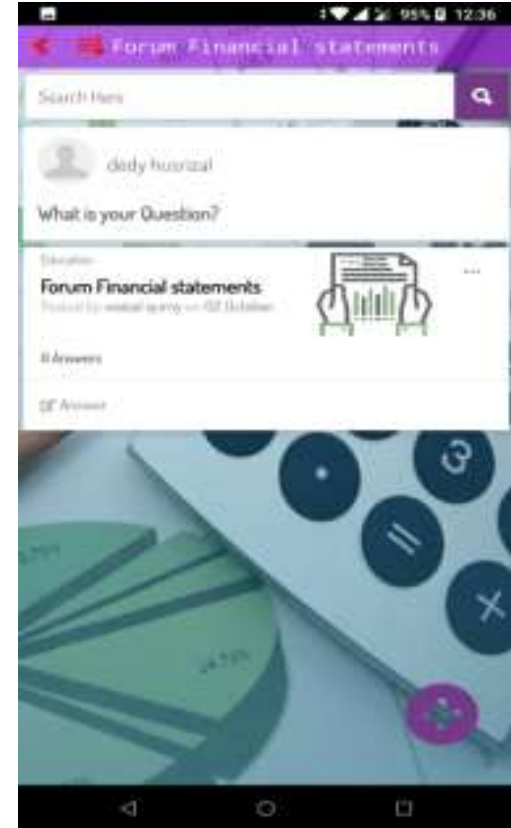

Figure 10. Discussion Forum Menu Display

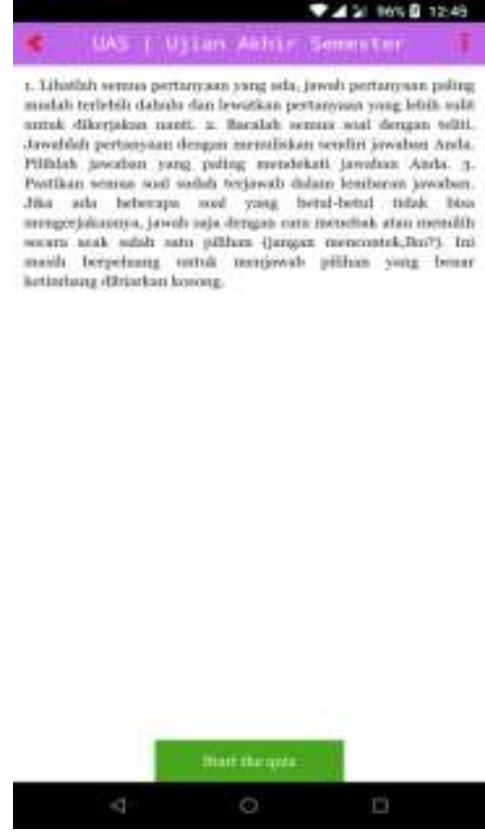

Figure 11. Testing Menu Display

Furthermore, the implementation of the students' analytical skills test was carried out on students who took courses on financial statement analysis totaling 40 students. In this stage, an N-Gain test is conducted to find out the improvement of students' academic abilities. Emphasis on enhanced ability is after students carry out learning with mobile learning media that have been developed before, then students are given test questions to analyze the financial statement transactions that exist in the company. The test is carried out twice, namely before using the media and after using the media. The result is that there are differences in students' academic abilities after using mobile learning media as shown in table 7. 
Table 7. The Results of student academic analysis skills.

\begin{tabular}{lccc}
\hline \multicolumn{1}{c}{ Explanation } & Pre-Test & Post-Test & n-Gain \\
\hline Sample & 40 & 40 & 40 \\
Mean & 54 & 81.625 & 0.6074 \\
Median & 55 & 85 & 0.6667 \\
Standard & 7.267 & 8.577 & 0.1642 \\
Deviation & & & \\
Minimum & 45 & 60 & 0.2 \\
Maximum & 75 & 95 & 0.875 \\
\hline
\end{tabular}

Table 8. The Recapitulation of student pretest and posttest results.

\begin{tabular}{ccccc}
\hline Pretest Score & $\mathrm{N}$ & & Postest Score & $\mathrm{N}$ \\
\cline { 1 - 2 } 55 & 7 & 60 & 1 \\
55 & 12 & 65 & 3 \\
60 & 11 & 75 & 9 \\
65 & 6 & 80 & 4 \\
70 & 1 & 85 & 15 \\
75 & 2 & 90 & 4 \\
\hline
\end{tabular}

Based on tables 7 and 8 above, it can be interpreted that with the use of learning media that is easy, the content presented also makes it easier for students to understand sample problems and students can do it over and over again, wherever and whenever they support the improvement of students' analytical skills in the subject of report analysis finance. From the above table also found an average increase in the results of the pretest-posttest with an n-Gain value of 0.6074 , which is included in the medium category. The results of this study are in line with the results of research conducted by Polonia (2015) and Listiaji (2015) that the development of mobile-based learning media can increase learning motivation in the learning process and be able to encourage it to achieve higher learning outcomes. This is also reinforced by several observations of students stating that with this learning media their satisfaction, enthusiasm, and interest in learning is increased.

\section{CONCLUSION}

The development of learning media based on mobile learning in the Financial Statement Analysis course for the Accounting Study Program of Medan State University has been successfully developed using the AppyPie is assisted with an image processing program, called by Corel Photoimpact. Based on the assessment by media experts on the development of mobile learning media learning is very viable. Likewise with the acquisition of student field trial evaluation results which are categorized as also very viable, therefore, the development of learning media Financial Reports based on mobile learning is worthy of being used as a medium of learning and independent learning resources. This mobile-based learning media research also resulted in an increase in students 'analytical skills on the Financial Statement Analysis course, this was also reinforced by some of the students' the response of students who are increasingly enthusiastic and interested in this subject.

However, if it is measured according to the level of student learning achievement, research on the development of mobile learning-based media cannot be done yet because it requires time adjustments until the end of the semester, and also has not reached yet the level of marketing via Google Play Store, only rated as limited 
to the feasibility of the media by validators and trials among students of Medan's state universities, so it is expected for the future to develop similar R\&D research by completing the level of playstore marketing so that the research object can be more extensive, and if necessary it can also compare between the use of mobile-based learning media and web-based.

\section{REFERENCES}

Anggraeni, R., \& Kustijono, R. (2013). Pengembangan Media Animasi Fisika Pada Materi Cahaya Dengan Aplikasi Flash Berbasis Android. Jurnal Penelitian Fisika Dan Aplikasinya (JPFA), 3(1), 11. https://doi.org/10.26740/jpfa.v3n1.p11-18

Aripin, I. (2018). Konsep Dan Aplikasi Mobile Learning Dalam Pembelajaran Biologi. Bio Educatio, 3(April), 1-9.

Asyhar, R. (2011). Kreatif mengembangkan Media Pembelajaran. Jakarta: Gaung Persada Press

Borg, W.R. \& Gall, M.D. (1983). Educational Research, An Introduction, Fourth Edition. In New York: Log-man Inc.

Calimag, J. a N. N. V, Miguel, P. A. G., Conde, R. S., \&amp; Aquino, L. B. (2014). Ubiquitous Learning Environment Using Android Mobile Application. International Journal of Research in Engineering and Technology, 2(2), pp 119128.

El-Mouelhy, I., Poon, I. H. C., Hui, A. N. N., \& Sue-Chan, C. (2013). Does a Creative Learning Medium Matter? Impact of Low Cost Android Tablets on Elementary Students' English Comprehension, Perceived Performance and Memory Retention. Creative Education, 04(12), 42-50. https:// doi.org/10.4236/ce.2013.412a2007

Febriani, A. S. (2017). FENOMENA PENGGUNAAN APLIKASI MEDIA SOSIAL BIGO LIVE ( LIVE STREAMING ) DI KALANGAN MAHASISWA FISIP UNPAS. Universitas Pasundan.

Hake, R. R. (1999). Analyzing change/gain scores. Unpublished.[Online] URL: Http://Www. Physics. Indiana. Edu/ $\sim$ Sdi/AnalyzingChange-Gain. Pdf.

Likert, R. (2017). The method of constructing an attitude scale. In Scaling: A Sourcebook for Behavioral Scientists (pp. 233-243). https:// doi.org/10.4324/9781315128948-23

Listiaji,P.(2015). Pengembangan Aplikasi MobileLearning sebagai PenunjangPembelajaran Fisika pada MateriHukum Gravitasi Newton untuk Siswa SMA.

Martikasari, K. (2018). Kahoot: Media Pembelajaran Interaktif Dalam Era Revolusi Industri 4.0. 181-189. https://doi.org/10.24071/snfkip.2018.19

Polonia,B.S. (2014). Pengembangan Aplikasi Kamus Aplikasi Berbasis Android sebagai Alternatif Sumber Belajar Mandiri Siswa Kelas X SMA Pokok Bahasan FluidaStatis dan Kalor. Jurnal Online Universitas Negeri Malang Vol.2. No. 1. (Online).

Sabiatus, Soibah, Lusia, R. (2015). Pengembangan Media Pembelajaran Interaktif Berbasis Lectora Pada Mata Pelajaran Teknik Elektronika Dasar Kelas X Tav Di Smk Negeri 7 Surabaya. Jurnal Pendidikan Teknik Elektro, 4(3).

Sugiyono. (2010). Metode Penelitian Bisnis. Pendekatan Kuantitatif, kualitatif dan R \& D. In Bandung: Alfabeta (Vol. 15). Bandung: Alfabeta. 
Sulastri, Y. L., \& Hakim, L. L. (2014). Pembelajaran Berbasis Mobile. Jurnal Pengajaran Matematika Dan Ilmu Pengetahuan Alam, 19(2), 173. https://doi.org/10.18269/jpmipa.v19i2.458

UNESCO. (2011). ICT Competency Framework for Teachers. Paris: UNESCO 2002.

Wartomo, 2016. (2016). Prosiding temu ilmiah nasional guru (ting) viii. Prosiding Temu Ilmiah Nasional Guru, 1-9(November), 632-641.

Yana, E., Swadaya, U., Jati, G., Komara, A., Swadaya, U., Jati, G., ... Mahasiswa, K. A. (2019). Pengembangan game edukatif berbasis android sebagai media pembelajaran akuntansi untuk meningkatkan analysis ability mahasiswa. Jurnal Assets Akuntansi Dan Pendidikan, 8(2), 157-173.

Yektyastuti, R., \& Ikhsan, J. (2016). Pengembangan media pembelajaran berbasis android pada materi kelarutan untuk meningkatkan performa akademik siswa SMA. Jurnal Inovasi Pendidikan IPA, 2(1), 88. https://doi.org/10.21831/jipi.v2i1.10289 